ISSN 0258-7122 (Print), 2408-8293 (Online)

Bangladesh J. Agril. Res. 43(3): 431-440, September 2018

\title{
MANAGEMENT OF BRINJAL SHOOT AND FRUIT BORER USING SELECTED BOTANICALS
}

\author{
H. SULTANA ${ }^{1}$, M. A. MANNAN ${ }^{2}$, M. M. KAMAL ${ }^{3}$ \\ K. G. QUDDUS ${ }^{4}$ AND S. DAS ${ }^{5}$
}

\begin{abstract}
The study was conducted to evaluate the effect of botanicals namely neem leaf extract, neem oil, mahogany oil, mahogany oil + mahogany cake, garlic extract, tobacco leaf extract along with an untreated control to manage brinjal shoot and fruit borer (BSFB). The percent shoot infestation reduction over control was the highest in mahogany oil + mahogany cake treated plot resulting $62.39 \%$, $64.44 \%, 67.86 \%$ and $71.05 \%$ reduction at vegetative stage and early, mid and late fruiting stage, respectively. The same treatment provided the highest fruit infestation reduction over control resulting $86.70 \%, 85.08 \%$ and $85.50 \%$ reduction at early, mid and late fruiting stage, respectively. The lowest number of larvae per infested shoot was recorded 1.10 and 1.08 in the same treatment at early and mid fruiting stage, respectively but notat vegetative stage and late fruiting stages. The number of larvae per infested fruit was similarly lowest having 1.50, 1.06 and 1.07 at early, mid and late fruiting stage, respectively using the same approach. The maximum yield $\left(35.82 \mathrm{t} \mathrm{ha}^{-1}\right)$ was achieved in the mahogany oil + mahogany cake treated plot with the highest benefit cost ratio (2.35).
\end{abstract}

Keywords: Leucinode sorbonalis, neem, mahogany, garlic, tobacco,extracts, oils, cake.

\section{Introduction}

Brinjal (Solanum melongena L.) is one of the most popular vegetables in South and South-East Asia (Thapa, 2010) having hot-wet climate (Hanson et al., 2006) and other parts of the world (Nonnecke, 1989). The cultivation of brinjal is more than 16.00 lakh producing around 50 million tons throughout the world (FAO, 2012). The higher yield and longer fruiting and harvesting period lure the farmer on eggplant production (Ghimire et al., 2007). In Bangladesh it covers about $15 \%$ of the total vegetable area of the country producing 1.6 million tons annually. The production of brinjal is $60-65 \mathrm{t} \mathrm{ha}^{-1}$ (BARI, 2005) which is not satisfactory to meet up the growing demand of vegetables. The production of brinjal is affected severely by different insect pests from seedling to fruiting stage (Latif et al., 2009). Brinjal shoot and fruit borer (Leucinodes

\footnotetext{
${ }^{1}$ Scientific Officer, Soil Resource Development Institute, Dhaka, ${ }^{2 \& 4}$ Professor, Agrotechnology Discipline, Khulna University, Khulna-9208, ${ }^{3 \& 5}$ Assistant Professor, Agrotechnology Discipline, Khulna University, Khulna-9208, Bangladesh.
} 
orbonalis, Guenee) is the most destructive insect pest of brinjal in Bangladesh which caused 31-86\% fruit damage (Alam et al., 2003) reaching up to $90 \%$ (Rahman, 1997). It also reduces the content of vitamin $\mathrm{C}$ in fruit up to 80 percent (Sharma, 2001). Farmers of Bangladesh as well as of other Asian countries in most cases solely depend on insecticides for the management of this pest. Such dependence on insecticides has created many problems such as very frequent application of insecticides (up to 140 times in a season in Jessore), excessive residues on marketed vegetables that concerns general consumer's health and the environment, pesticide resistance, trade implications, poisoning, hazards to non-target organisms, increased production costs etc. (Alam et al., 2003; Pedigo, 2002).

Now-a-days, emphasis is given on the use of plant extracts as biopesticides in insect control measures (Singh et al., 2007; Gupta and Raghuraman, 2004; Oerke, 2006; Gokce, 2010). This is because that the use of plant based biopesticides in insect control is non-toxic and safe biodegradable alternatives to the conventional chemical control (Anil and Pandey, 2001; Dolui and Debnath, 2010). So, for ensuring food safety and minimization environmental hazards the present study was undertaken to determine the effectiveness of selected botanicals for the management of brinjal shoot and fruit borer (BSFB).

\section{Materials and Methods}

\section{Experimental site and climatic condition}

The experiment was conducted in the Field Laboratory of Agrotechnology Discipline, Khulna University, Khulna $\left(22^{\circ} 47^{\prime} 57.84^{\prime \prime} \mathrm{N}, 89^{\circ} 31^{\prime} 53.48^{\prime \prime} \mathrm{E}\right)$, Bangladesh during December 2013 to June 2014. The experimental site was characterized by moderately high temperature and heavy rainfall during kharif season (April-October) and scantly rainfall with moderately low temperature during rabi season (November-March).

\section{Raising of seedlings and transplanting}

The seed of local brinjal variety named Makra was collected from local market Gollamari and raised as seedling in germplasm centre of Khulna University. Brinjal seedling was raised in seedbed of $3 \mathrm{~m} \times 1 \mathrm{~m}$ size. Weeding, mulching and irrigation were done when required. The experiment was laid out in the Randomized Complete Block Design (RCBD) with three replications. The entire experimental plot was divided into 3 blocks each containing 7 units plots. Totally there were 21 unit plots. The treatments were randomly assigned to each unit plot so as to allot one treatment combination once in each block. The unit plots were $3 \mathrm{~m} \times 2 \mathrm{~m}$ in size with $75 \mathrm{~cm}$ distance between the blocks and $50 \mathrm{~cm}$ between the unit plots. Each plot was contained 16 plants. Organic amendments and chemical 
fertilizers were applied in the field as recommended by Bangladesh Agricultural Research Council (Anon., 2005). Healthy seedlings were uprooted from the seedbed and were transplanted in the experimental plots during late afternoon on December, 2013. Immediately after planting, the seedlings were watered. Seedlings were also planted around the experimental area for gap filling and to check the border effect.

\section{Preparation of neem leaf extract}

Fresh leaves of Azadirachata indica (Neem) were collected from the plants at the Khulna University campus. Then the collected leaves were dried in shade and were ground with a domestic grinder. Fifty grams $(50 \mathrm{~g})$ of the ground leaves were added with water and left overnight to make $1000 \mathrm{ml}$ solution. The mixture was then filtered and the filtrate poured into a flat bottom flask as stock for the field spraying five grams of wheel powder was added to increase its adhesiveness (Murugesam and Murugesh, 2009).

\section{Preparation of garlic extract}

Bulbs of garlic were brought from the market, $30 \mathrm{~g}$ of garlic bulbs were chopped into pieces using knife and such material was ground thoroughly, mixed with 50 $\mathrm{ml}$ of water and the ground mixture was soaked in little quantity of water over night and squeezed through muslin cloth and the volume was made up to 1 liter to get 3 per cent extract five grams of wheel powder was added to increase its adhesiveness (Murugesam and Murugesh, 2009).

\section{Preparation of tobacco leaf extract}

Tobacco leaves were brought from the market, $30 \mathrm{~g}$ of tobacco leaves were chopped into pieces and such material was ground thoroughly in mixed with 50 $\mathrm{ml}$ of water and the ground mixture was soaked in little quantity of water over night and squeezed through muslin cloth and the volume was made up to 1 liter to get 3 per cent extract five gram of wheel powder was added to increase its adhesiveness (Murugesam and Murugesh, 2009).

The neem oil, mahogany oil and mahogany cake were purchased from the local market of Khulna.

\section{Treatment application}

The treatments namely Untreated control (only water), Neem leaf extract (@50 $\mathrm{gl}^{-1}$ water), Neem oil (@40 ml 1-1 water), Mahogany oil (@ $40 \mathrm{ml} \mathrm{l}^{-1}$ water), Mahogany oil + Mahogany cake (oil (@ $40 \mathrm{ml} \mathrm{l}^{-1}$ water + cake @ $250 \mathrm{~kg} \mathrm{ha}^{-1}$ ),

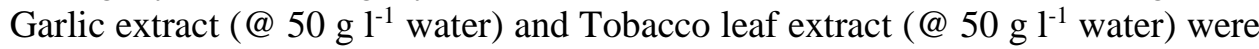
applied as foliar sprays starting after 20 days of transplanting and repeated 
subsequently at 7 days interval and mahogany cake was applied in the plot and incorporated with soil. Care was taken to avoid drifting of treatment to neighbouring plots. No pest control technique was applied in untreated control plots. However, an equal volume of water, which was used for other plots, was sprayed at 7 days intervals. After transplanting of seedlings, various intercultural operations were accomplished for better growth and development of the plants.

\section{Harvesting and data collection}

Harvesting of fruits was started at 60 days after transplanting and continued up to 150 days after transplanting with an interval of 7 days. Harvesting was usually done manually. In order to know the effects of the treatments on controlling BSFB. Data were collected on total numbers of shoot, total numbers of infested shoot, percentage of shoots damage, percentage reduction of shoots infestation, numbers of larvae per infested shoot, total numbers of fruits, percentage of fruits damage, percentage reduction of fruits infestation, numbers of larvae per infested fruits, cost of production, gross return and benefit cost ratio (BCR).

\section{Data analysis}

Data were analyzed by using MSTAT-C software for analysis of variance. ANOVA was made by $\mathrm{F}$ variance test and the pair comparisons were performed by Duncan's Multiple Range Test (DMRT).

\section{Results and Discussion}

The percent shoot infestation reduction over control by brinjal shoot and fruit borer (BSFB) in different stages was statistically significant (Table 1). Among the seven treatments the highest percent shoot infestation reduction over control was observed in mahogany oil + mahogany cake (62.39\%) treated plot and the lowest in the mahogany oil $(25.93 \%)$ treated plot at vegetative stage. At early fruiting stage, the highest $(64.44 \%)$ percent shoot infestation reduction over control was found in mahogany oil + mahogany cake and the lowest in the garlic extract treated plot $(28.60 \%)$. Whereas, at the mid fruiting stage, the percent shoot infestation reduction over control was the highest $(67.86 \%)$ in mahogany oil + mahogany cake and the lowest $(31.82 \%)$ in garlic extract sprayed fields. Finally at late fruiting stage, the highest percent shoot infestation reduction over control $(71.05 \%)$ was recorded from mahogany oil + mahogany cake and the lowest $(27.63 \%)$ in the garlic extract applied plot.

From the result, it was revealed that at all the growth stages of brinjal percent shoot infestation reduction over control was the highest in mahogany oil + mahogany cake and the lowest in the garlic extract. Botanicals are more advantageous over insecticides (Prakash et al., 2008), as they fit well in IPM. 
The safer plant products are useful in developing sound pest management strategies (Gupta and Singh, 2002). Among the plant extract treatments, more protection of shoot over control was found from neem leaf extract $(92.5 \%)$ followed by tobacco leaf extract $(84.4 \%)$ and mahogony seed extract (60.40\%) (Ashadul et al., 2014). Dutta et al. (2011) found that simultaneous application of trap and neem extract afforded $79.24 \%$ protection against shoot damage.

Table 1. Percent shoot infestation reduction over control at different stages

\begin{tabular}{l|c|c|c|c}
\hline \multicolumn{1}{c}{ Treatments } & $\begin{array}{c}\text { Vegetative } \\
\text { stage }(30-60 \\
\text { DAT) }(\%)\end{array}$ & $\begin{array}{c}\text { Early fruiting } \\
\text { stage }(60-90 \\
\text { DAT) }(\%)\end{array}$ & $\begin{array}{c}\text { Mid fruiting } \\
\text { stage }(90-120 \\
\text { DAT) }(\%)\end{array}$ & $\begin{array}{c}\text { Late fruiting } \\
\text { stage }(120-150 \\
\text { DAT) }(\%)\end{array}$ \\
\hline Control & $0.00 \mathrm{c}$ & $0.00 \mathrm{f}$ & $0.00 \mathrm{~d}$ & $0.00 \mathrm{e}$ \\
Neem leaf extract & $40.00 \mathrm{ab}$ & $32.33 \mathrm{de}$ & $42.00 \mathrm{bc}$ & $42.11 \mathrm{c}$ \\
Neem oil & $59.26 \mathrm{a}$ & $55.67 \mathrm{ab}$ & $65.38 \mathrm{a}$ & $64.85 \mathrm{ab}$ \\
Mahogony oil & $25.93 \mathrm{~b}$ & $40.37 \mathrm{~cd}$ & $39.58 \mathrm{bc}$ & $37.28 \mathrm{~cd}$ \\
Mahogany oil + Mahogany & $62.39 \mathrm{a}$ & $64.44 \mathrm{a}$ & $67.86 \mathrm{a}$ & $71.05 \mathrm{a}$ \\
cake & $27.78 \mathrm{~b}$ & $28.60 \mathrm{e}$ & $31.82 \mathrm{c}$ & $27.63 \mathrm{~d}$ \\
Garlic extract & $40.74 \mathrm{ab}$ & $46.97 \mathrm{bc}$ & $45.00 \mathrm{~b}$ & $56.58 \mathrm{~b}$ \\
Tobacco leaf extract & $* *$ & $* *$ & $* *$ & $* *$ \\
\hline Level of significance & 26.74 & 10.05 & 9.97 & 13.33 \\
CV $(\%)$ &
\end{tabular}

DAT $=$ Days After Transplanting; $* *=$ Significant at $1 \%$ level; $\mathrm{CV}=$ Coefficient of Variation.

Means followed by common letter(s) in a column do not differ significantly by DMRT.

The percent fruit infestation reduction over control at different stages was statistically significant (Table 2). Percent fruit infestation reduction over control was the highest inmahogany oil + mahogany cake $(86.70 \%, 85.08 \%$ and $85.50 \%)$ at early, mid and late fruiting stage, respectively. The lowest percent of fruit infestation eduction over control was found in garlic extract $(17.40 \%, 9.06 \%$ and $9.80 \%$ ) at early, mid and late fruiting stage, respectively. It was recommended that innovative methods of application, proper timing and aqueous neem seed extract can be other alternative or supplement to synthetic insecticide for the management of vegetable pests by poor farmers (Owusu-Ansah et al., 2001). Among the plant extract treatments, more protection of fruit over control was found from neem leaf extract $(93.30 \%)$ followed by tobacco leaf extract $(84.30 \%)$ and mahogony seed extract $(73.00 \%)$ (Ashadul et al., 2014). Application of trap and peak neem afforded $47.70 \%$ protection against fruit damage (Dutta et al., 2011). 
Table 2. Percent fruit infestation reduction over control at different stages

\begin{tabular}{lcccc}
\hline \multicolumn{1}{c}{ Treatments } & $\begin{array}{c}\text { Early fruiting stage } \\
(60-90 \text { DAT) }(\%)\end{array}$ & $\begin{array}{c}\text { Mid fruiting stage } \\
(90-120 \text { DAT })(\%)\end{array}$ & $\begin{array}{c}\text { Late fruiting stage } \\
(120-150 \text { DAT })(\%)\end{array}$ \\
\hline Control & $0.00 \mathrm{~g}$ & $0.00 \mathrm{e}$ & $0.00 \mathrm{~g}$ \\
Neem leaf extract & $43.90 \mathrm{~d}$ & $41.10 \mathrm{bc}$ & $38.90 \mathrm{~d}$ \\
Neem oil & $71.90 \mathrm{~b}$ & $44.30 \mathrm{~b}$ & $69.50 \mathrm{~b}$ \\
Mahogony oil & $31.50 \mathrm{e}$ & $25.60 \mathrm{~cd}$ & $25.90 \mathrm{e}$ \\
Mahogany oil $\quad+$ & $86.70 \mathrm{a}$ & $85.80 \mathrm{a}$ & $85.50 \mathrm{a}$ \\
Mahogany cake & $17.40 \mathrm{f}$ & $9.06 \mathrm{de}$ & $9.80 \mathrm{f}$ \\
Garlic extract & $57.40 \mathrm{c}$ & $58.20 \mathrm{~b}$ & $58.70 \mathrm{c}$ \\
Tobacco leaf extract & $* *$ & $* *$ & $* *$ \\
Level of significance & 5.45 & 16.29 & 7.73 \\
CV $(\%)$ & & &
\end{tabular}

DAT $=$ Days After Transplanting; $* *=$ Significant at $1 \%$ level; $\mathrm{CV}=$ Coefficient of Variation.

Means followed by common letter(s) in a column do not differ significantly by DMRT.

Number of larvae in infested shoot and fruit atdifferent stages was statistically significant (Table 3). The highest number of larvae per infested shoot was recorded (3.10) in the control and the lowest (1.00) in neem oil which was statistically similar to mahogany oil + mahogany cake (1.09). Mean number of larvae per infested shoot at early fruiting stage was recorded the lowest in mahogany oil + mahogany cake (1.10) preceded by neem oil (1.40) and the highest was recorded from the control (2.50). The mean number of larvae per infested shoot at mid fruiting stage was the highest in control (2.50) and the lowest in mahogany oil + mahogany cake (1.08). Mean number of larvae per infested shoot at late fruiting stage was found the highest (2.30) in control and the lowest (1.07), in mahogany oil + mahogany cake. Mean number of larvae per infested fruit plant at early fruiting stage was observed the highest in the control (3.20) and the lowest in mahogany oil + mahogany cake (1.06). Mean number of larvae per infested fruit plant at mid fruiting stage was the highest in the control (3.20) and the lowest in mahogany oil + mahogany cake (1.06). Mean number of larvae per infested fruit plant at late fruiting stage was the highest in the control (3.20) and the lowest in mahogany oil + mahogany cake (1.07) followed by neem oil (1.10). 
Table 3. Mean number of larvae per infested shoot and per infested fruit at different stages

\begin{tabular}{|c|c|c|c|c|c|c|c|}
\hline \multirow[b]{2}{*}{ Treatments } & \multicolumn{4}{|c|}{ Mean number of larvae per infested shoot } & \multicolumn{3}{|c|}{$\begin{array}{l}\text { Mean number of larvae per } \\
\text { infested fruit }\end{array}$} \\
\hline & $\begin{array}{c}\text { Vegetative } \\
\text { stage }(30- \\
\text { 60DAT) }\end{array}$ & $\begin{array}{c}\text { Early } \\
\text { fruiting } \\
\text { stage }(60- \\
90 \text { DAT) }\end{array}$ & $\begin{array}{c}\text { Mid } \\
\text { fruiting } \\
\text { stage } \\
(90-120 \\
\text { DAT) }\end{array}$ & \begin{tabular}{|} 
Late \\
fruiting \\
stage \\
$(120-150$ \\
DAT $)$
\end{tabular} & $\begin{array}{c}\text { Early } \\
\text { fruiting } \\
\text { stage }(60- \\
90 \text { DAT) }\end{array}$ & $\begin{array}{c}\text { Mid } \\
\text { fruiting } \\
\text { stage } \\
(90-120 \\
\text { DAT })\end{array}$ & $\begin{array}{c}\text { Late } \\
\text { fruiting } \\
\text { stage } \\
(120-150 \\
\text { DAT) }\end{array}$ \\
\hline Control & $3.10 \mathrm{a}$ & $2.50 \mathrm{a}$ & $2.50 \mathrm{a}$ & $2.30 \mathrm{a}$ & $3.80 \mathrm{a}$ & $3.20 \mathrm{a}$ & $3.20 \mathrm{a}$ \\
\hline $\begin{array}{l}\text { Neem leaf } \\
\text { extract }\end{array}$ & $1.70 \mathrm{bc}$ & $2.10 \mathrm{ab}$ & $2.00 \mathrm{a}$ & $1.90 \mathrm{a}$ & $1.90 \mathrm{c}$ & $1.50 \mathrm{bc}$ & $1.40 \mathrm{bc}$ \\
\hline Neem oil & $1.00 \mathrm{c}$ & $1.40 \mathrm{c}$ & $1.30 \mathrm{~b}$ & $1.20 \mathrm{~b}$ & $1.70 \mathrm{c}$ & $1.30 \mathrm{bc}$ & $1.10 \mathrm{c}$ \\
\hline Mahogany oil & $2.30 \mathrm{~b}$ & $2.40 \mathrm{a}$ & $2.20 \mathrm{a}$ & $2.10 \mathrm{a}$ & $1.80 \mathrm{c}$ & $1.90 \mathrm{~b}$ & $1.80 \mathrm{~b}$ \\
\hline $\begin{array}{l}\text { Mahogany oil } \\
+ \text { Mahogany } \\
\text { cake }\end{array}$ & $1.09 \mathrm{c}$ & $1.10 \mathrm{c}$ & $1.08 \mathrm{~b}$ & $1.07 \mathrm{~b}$ & $1.50 \mathrm{c}$ & $1.06 \mathrm{c}$ & $1.07 \mathrm{c}$ \\
\hline $\begin{array}{l}\text { Garlic } \\
\text { extract }\end{array}$ & $2.20 \mathrm{~b}$ & $2.30 \mathrm{a}$ & $2.10 \mathrm{a}$ & $2.00 \mathrm{a}$ & $2.40 \mathrm{~b}$ & $1.90 \mathrm{~b}$ & $1.60 \mathrm{bc}$ \\
\hline $\begin{array}{l}\text { Tobacco leaf } \\
\text { extract }\end{array}$ & $1.30 \mathrm{c}$ & $1.50 \mathrm{bc}$ & $1.30 \mathrm{~b}$ & $1.00 \mathrm{~b}$ & $1.50 \mathrm{c}$ & $1.30 \mathrm{bc}$ & $1.20 \mathrm{bc}$ \\
\hline LS & $* *$ & $* *$ & $* *$ & $* *$ & $* *$ & $* *$ & $* *$ \\
\hline CV (\%) & 14.46 & 12.04 & 10.51 & 10.59 & 10.28 & 15.010 & 13.52 \\
\hline
\end{tabular}

DAT $=$ Days After Transplanting; LS $=$ Level of Significance; $* *=$ Significant at $1 \%$ level $\mathrm{CV}=$ Coefficient of Variation.

Means followed by common letter(s) in a column do not differ significantly by DMRT.

The yield per plot showed significant variation among the treatments (Table 4). The yield was highest $\left(35.82 \mathrm{tha}^{-1}\right)$ when mahogany oil + mahogany cake was applied which was statistically identical with tobacco leaf extract $\left(33.97 \mathrm{t} \mathrm{ha}^{-1}\right)$ treated field plot. Increased yield over control was highest in mahogany oil + mahogany cake $\left(19.34 \mathrm{t} \mathrm{ha}^{-1}\right)$ treatment and the lowest was in garlic extract treated plot $\left(5.34 \mathrm{t} \mathrm{ha}^{-1}\right)$.

According to the procedure of Ramakrishna and Palled (2005), cost and return analysis in details was done and has been shown in Table 5. Material, nonmaterial and overhead cost were recorded for all treatments on unit plot basis and calculated per hectare. The total cost of production ranged between $291666 \mathrm{Tk}$. and $491666 \mathrm{Tkha}^{-1}$. The highest cost of production was found in neem oil $\left(491666 \mathrm{Tkha}^{-1}\right.$ ) followed by tobacco leaf extract (411666) and the lowest was found in the control $\left(291666 \mathrm{Tkha}^{-1}\right)$. The range between the gross return was 
$264000 \mathrm{Tk}$ to $949700 \mathrm{Tkha}^{-1}$. The treatment mahogany oil + mahogany cake gave the highest net return of Tk. 949700 followed by tobacco leaf extract of Tk. 888200 and the lowest was found in control $\left(264000 \mathrm{Tkha}^{-1}\right)$. The maximum benefit cost ratio was found (2.35) in the mahogany oil + mahogany cake which was statistically similar with tobacco leaf extract (2.16) and the minimum was in untreated control (0.91) plot.

Considering the economic return per hectare, this experiment demonstrated that application of mahogany oil + mahogany cake was found more appropriate for brinjal production for controlling brinjal shoot and fruit borer.

Table 4. Effect of selected botanicals on brinjal yield

\begin{tabular}{lcc}
\hline Treatments & Yield $\left(\mathrm{t} \mathrm{ha}^{-1}\right)$ & Increased yield over control $\left(\mathrm{t} \mathrm{ha}^{-1}\right)$ \\
\hline Control & $16.48 \mathrm{~d}$ & $0.00 \mathrm{~d}$ \\
Neem leaf extract & $25.32 \mathrm{bc}$ & $8.84 \mathrm{bc}$ \\
Neem oil & $30.85 \mathrm{ab}$ & $14.37 \mathrm{ab}$ \\
Mahogony oil & $23.32 \mathrm{~cd}$ & $6.84 \mathrm{~cd}$ \\
Mahogany oil + Mahogany cake & $35.82 \mathrm{a}$ & $19.34 \mathrm{a}$ \\
Garlic extract & $21.82 \mathrm{~cd}$ & $5.34 \mathrm{~cd}$ \\
Tobacco leaf extract & $33.97 \mathrm{a}$ & $17.49 \mathrm{a}$ \\
Level of significance & $* *$ & $* *$ \\
CV $(\%)$ & 11.17 & 22.18 \\
\hline
\end{tabular}

**= Significant at $1 \%$ level; $\mathrm{CV}=$ Coefficient of Variation.

Means followed by common letter(s) in a column do not differ significantly by DMRT.

Table 5. Benefit Cost Ratio of brinjal production

\begin{tabular}{lcc|c}
\hline Treatments & $\begin{array}{c}\text { Gross return } \\
\left(\text { Tkha }^{-1}\right)\end{array}$ & $\begin{array}{c}\text { Total cost of } \\
\text { production }\left(\mathrm{Tkha}^{-1}\right)\end{array}$ & $\begin{array}{c}\text { Benefit cost } \\
\text { ratio(BCR) }\end{array}$ \\
\hline Control & $264000 \mathrm{~g}$ & 291666 & $0.910 \mathrm{c}$ \\
Neem leaf extract & $573200 \mathrm{~d}$ & 341666 & $1.68 \mathrm{~b}$ \\
Neem oil & $808500 \mathrm{c}$ & 491666 & $1.64 \mathrm{~b}$ \\
Mahogany oil & $448200 \mathrm{e}$ & 391666 & $1.14 \mathrm{c}$ \\
Mahogany oil + Mahogany cake & $949700 \mathrm{a}$ & 403333 & $2.35 \mathrm{a}$ \\
Garlic extract & $403200 \mathrm{f}$ & 361666 & $1.11 \mathrm{c}$ \\
Tobacco leaf extract. & $888200 \mathrm{~b}$ & 411666 & $2.16 \mathrm{a}$ \\
\hline Level of significance & $* *$ & $\mathrm{NS}$ & $* *$ \\
CV $(\%)$ & 11.47 & - & 12.19 \\
\hline
\end{tabular}

$* *=$ Significant at $1 \%$ level; $\mathrm{NS}=$ Non Significant $\mathrm{CV}=$ Coefficient of Variation.

Means followed by common letter(s) in a column do not differ significantly by DMRT 


\section{Conclusion}

The findings of the present study revealed that mahogany oil + mahoganycake, was proved to be highly effective against BSFB and cost effective. So, brinjal growers may be motivated to apply mahogany (oil + cake) for better management of brinjal shoot and fruit borer (BSFB) to ensure maximum yield.

\section{References}

Alam, S. N., M. A. Rashid, F. M. A. Rouf, R. C. Jhala, J. R. Patel, S. Satpathy, T.M. Shivalingaswamy, S. Rai, I. Wahundeniya, A. Cork, C. Ammaranan and N. S. Talekar. 2003. Development of an integrated pest management strategy for eggplant fruit and shoot borer in South Asia. Technical Bull. 28. AVRDC- The world Vegetable Centre, Shanhua, Taiwan. 56p.

Anil, K. and M. C. Pandey. 2001. Role of Bio pesticides in plant protection system. Biopest Conf. BET., Chandigarh, India. P.113.

Anonymous. 2005. Fertilizer Recommendation Guide. Bangladesh Agricultural Research Council (BARC). New Airport Road, Farmgate, Dhaka 1215.

Ashadul, M.I., M.A. Hussain, S.A. Shapla, H. Mehraj and A.F.M. Jamal Uddin. 2014. Plant Extract for the Management of Brinjal Shoot and Fruit Borer (Leucinodes orbonalis Guenee). American-Eurasian J. Agric. \& Environ. Sci. 14 (12): 14091414.

BARI (Bangladesh Agricultural Research Institute). 2005. Annual Research Report. 1993-94. Joydebpur, Gazipur, Bangladesh: BARI. P. 319.

Dolui, A. K. and M. Debnath. 2010. Antifeedant activity of plant extracts to an insect Helopeltistheivora. J. Environ. Biology. 31(5): 557-559.

Dutta, P., A.K. Singha, P. Das and S. Kalita, 2011. Management of brinjal fruit and shoot borer, Leucinodes orbanalisin agro-ecological condition of West Tripura. Scholarly J. Agric. Sci. 1(2): 16-19.

FAO (Food and Agricultural Organization). 2012. FAOSTAT data 2012 (Avalilable at: http://www.fao.org Retrived on 25 February, 2014).

Ghimire, S. N., G. Upreti, R. B. Thapa and D. N. Manandhar. 2007. Ecofriendly management of brinjal fruit and shoot borer, Leucinodes orbonalis Guenee (Lepidoptera: Pyralidae). IAAS Res. Advances. 2: 127-131.

Gokce, A. 2010. Toxicity and Antifeedant activity of selected plant extract against larval obliquebanded leaf roller Choristoneurar osateana (Harris). The Open Entom.4: 18-24.

Gupta, G. P. and M. Raghuraman. 2004. Utilization of biopesticides in cotton pest management In: Biopesticides for sustainable agriculture: prospects and constraints. (Kaushik, N., Ed.) CAB abstracts Teri Press, The Energy and Resource Institute. P. 43.

Gupta, R. C. and N. P. Singh. 2002. Neem: A natural pesticide for sustainable agriculture. Pestology. 26 (8): 50-57.

Hanson, P. M., R, Y. Yang, S. C. S. Tsou, D. Ledesma, L. Engle and T. C. Lee. 2006. Diversity of eggplant (Solanum melongena) for superoxide scavenging activity, total phenolics and ascorbic acid. J. of Food composition and Analysis. 19 (6-7): 594-600. 
Latif M. A., M. M. Rahman, M. Z. Alam and M. M. Hossain. 2009. Evaluation of Flubendiamide as an IPM Component for the Management of Brinjal Shoot and Fruit Borer, Leucinodes Orbonalis Guenee. Mun. Ent. Zool.4 (1): 257-267.

Murugesam, N. and T. Murugesh. 2009. Bioefficacy of some plant products against brinjal fruit borer, LeucinodesorbonalisGuenee (Lepidoptera: Pyrallidae). J. Biopesticides. 2 (1): 60-63.

Nonnecke, J. L. 1989. Vegetable Production. Van Nostrand Reinhold, New York, Pp: 247.

Oerke, E. C. 2006. Crop losses to pests. J. Agric. Sci. 144: 31-43.

Owusu-Ansah, F., K. Afreh-Nuamah, D. Obeng-Ofori and K. G. Ofosu-Budu. 2001. Managing infestation levels of major insect pests of garden eggs (Solanum integrifolium L.) with aqueous neem seed extracts. J. Ghana Sci. Assoc. 3 (3): 70-84.

Pedigo, L. P. 2002. Entomology and Pest Management. 4th Edition. Prentice Hall, Upper Saddle River, New Jersey, USA. p. 633.

Prakash, A., J. Rao and V. Nandagopal. 2008. Future of botanical pesticides in rice, wheat, pulses and vegetables pest management. J. Biopesticides. 1(2): 154-169.

Rahman, A. K. M. Z. 1997. Screening of 28 brinjal line for resistance/tolerance against the brinjal shoot and fruit borer. Annual Report. Entomology Division, Bangladesh Agricultural Research Institute, Joydebpur, Gazipur, Bangladesh. pp. 32-35.

Ramakrishna, T. and Y. B. Palled. 2005. Effect of Plant Geometry and Fertilizer Levels Growth and Yield of Chilli. Karnataka J. Agric. Sci.18: 892-895

Rath, L. K. and B. K. Maity. 2005. Evaluation of a non-chemical IPM module for management of brinjal shoot and fruit borer. J. Appl. Zool. Res. 16 (1): 3-4.

Sharma, V., R. Lal and A. Choudhary. 2001. Screening of brinjal (Solanum spp.) germplasm against shoot and fruit borer, Leucinodes orbonalis Guenee. Insect Environ. 7 (3): 126-127.

Singh, K. I., S. Athokpam, M. P. Singh, T. R. Singh and N. G. Singh. 2007. Effect of planting dates on incidence of the shoot and fruit borer, Leucinodes orbonalis (Guenee.) and its seasonal abundance in brinjal crop at Manipur climate. J. Appl. Zool. Res. 18 (1):15-20.

Thapa, R. B. 2010. Integrated management of brinjal fruit and shoot borer, LeucinodesorbonalisGuenee: An overview. J. Inst. Agric. Anim. Sci.30 \& 32: 1-16. 